\title{
Marketing Tools as a Way to Promote Tourism Destination
}

\author{
S.A. Esipova ${ }^{1}$ O.V. Gokova ${ }^{2, *}$ \\ ${ }^{1}$ Ugra State University, Khanty-Mansi Autonomous Okrug-Yugra, Khanty-Mansiysk 628012, Russian Federation \\ ${ }^{2}$ Dostoevsky Omsk State University, Omsk 644077, Russian Federation \\ *Corresponding author. Email: capri484@yandex.ru
}

\begin{abstract}
The United Nations World Tourism Organization (UNWTOO) gives priority to a tourism destination as a key object in the process of tourism product formation [1]. A tourism destination - is a territory that attracts tourists with its natural, infrastructural, sporting recreational and etc. capacity with the aim of holding tourism activities in here further. Complex tourism destinations consist of tourism attractions, infrastructure and accompanying services. Currently, there are a lot of tourism destinations around the world, but not each can boast of its difference and creativity in the promotion of its tourist product. In relation to that each territory is becoming interchangeable and exhaustible, resulting in a reduction in tourist arrivals. To prevent that, it is necessary to apply marketing techniques as a tool for attracting tourism flows.
\end{abstract}

Keywords: tourism, destinations, marketing of tourism destinations, attractiveness, the attraction of

destinations, marketing tool

\section{INTRODUCTION}

For the development and management of attractive tourism territories, it is used to speaking in terms of marketing of tourism destinations or territorial (regional) tourist marketing, which constitutes an integral part of the complex development of tourist territories. Marketing of tourist destinations should be considered as a management process, in the framework of which the authorities of destination and business determine the target groups of tourists, establish communications with them, find out the preferences of tourists, their expectations, motivation to choose the place of travel in order to adapt the tourist product in accordance with the expectations of tourists to achieve their maximum satisfaction [3, p. 25].

\subsection{Paper Structure}

The article is organized as follows. Section 1 presents an analysis of the data of the Office of the Federal Service of State Statistics for the Tyumen Region, Khanty-Mansi Autonomous District - Ugra and Yamalo-Nenets Autonomous District, from which positive dynamics in key indicators of tourism activity are visible. Section 2 contains information on the marketing tools currently used to promote the region in the external and domestic tourism market and the methods we recommend. Section 3 completes and presents the risks and projected outcome as marketing policy changes in the Autonomous District.

Regulatory documentation regulating the brand formation and positioning of Ugra at the domestic, macro-regional, national, international levels has been studied.
The dynamics of tourism activity in the autonomous district for 3 years has been analyzed, based on its main indicators.

Existing approaches to territorial branding, ensuring the presence of the Ugra brand in the information space both national and international, the use of such a strategic resource in the development of territorial marketing as communications in the Internet space has been studied.

\subsection{Our Contribution}

We developed recommendations to promote the tourism potential of Khanty-Mansi Autonomous District - Ugra in the Internet space, as a key driver in the promotion of tourist destination.

\section{BACKGROUND}

The marketing concept is based on the product, which means all that can be offered to the market to meet needs and desires, including services, goods, events, organizations, information, places and territories [4].

The group of theorists headed by E.A. Kachagin notes that the principles of marketing operate equally for different objects, i.e. the marketing of the organization is a prototype of marketing of any object to which the marketing approach is applied, including territories [5]. Mass research on brand creation and development in marketing refers to the 1970s. The term "place branding" was introduced into scientific circulation by S. Anholt in 2002, which led to the mainstreaming of the problem of territory branding on the basis of marketing. It was under 
It should be noted that the growth of the volume of paid tourist services provided to the population by tourist agencies, tour operators (as well as other booking services and related services), amounted to 2190.1 million rubles, which is $8 \%$ more than in 2016 (1,968.9 million rubles), the volume of paid services provided by hotels and similar accommodation facilities increased by $2 \%$ compared to 2016 and in 2018 amounted to 1882.7 million rubles (Figures 3 and 4).

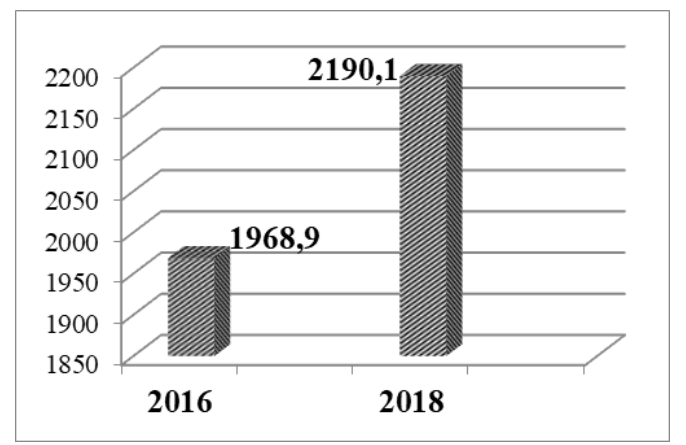

Figure 3 The volume of paid tourist services rendered to the population, million rubles

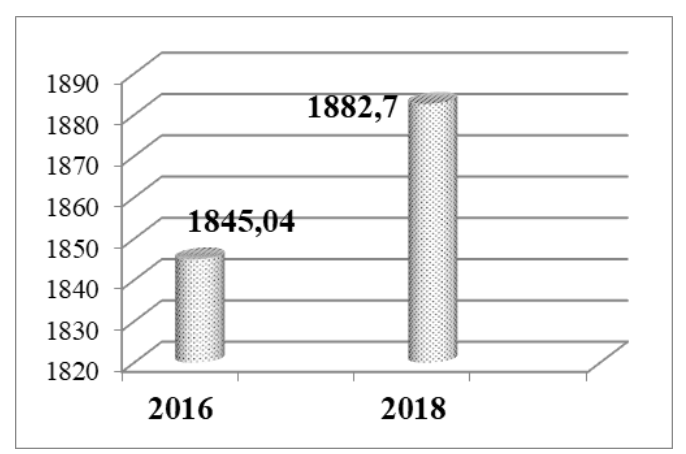

Figure 4 The volume of paid services rendered to the population by means of placement, million rubles

Currently, the following promotion technologies are used in the Autonomous District to position the tourist potential of KHMAO-Ugra in the territory of the Russian Federation and abroad:

1) the brand "See Ugra - fall in love with Russia";

2) participation in interregional and international events, main: "Inturmarket" International Tourism Market (ITM) and MITT Moscow International Travel \& Tourism;

3) creation and formation of the image of the Autonomous district as a region favorable for tourism through various levels of activities: International IT Forum with BRICS and SCO countries, international chess competitions, Biathlon, skiing, judo, Continental Hockey League games, international film debut festival "Spirit of Fire", International environmental action "Save and Preserve", Festival of Arts, Labor, and Sports "Samotlor Nights", Festival of Historical Modeling and Ethnic Music "Mangazey Move", All-Russian Congress of Father

Figure 2 Growth of tourist flow in KHMAO-Yugra, thousand people 
Christmas and Snow Maiden, event project "KhantyMansiysk - Capital of New Year day" etc.

The following Internet resources inform the nation about the tourist possibilities of Ugra:

- Site "Tourism in Ugra" (www.tourism.admhmao.ru);

- National travel portal Russian Travel;

- Portal "National calendar of events";

- Websites of municipal administrations of the autonomous district;

- Websites of organizations of the tourism industry of the autonomous district;

- The official account on the social network "Instagram".

A network of tourist information centers (TICs) has also been established and is functioning in the Autonomous District.

All this is done in accordance with the Concept of Development of Territorial Marketing and Branding in Khanty-Mansi Autonomous District - Ugra until 2025, approved by the Order of the Government of KhantyMansi Autonomous District - Ugra of October 19, 2018, № 539-rp.

In October-December 2019, a survey of residents of Ugra, Ural Federal District and representatives of the tour operator community outside KHMAO was conducted. Analyzing the obtained data, it can be said that there is a need for additional measures to inform about the tourist opportunities of Ugra, with special attention to Internet promotion. Respondents also noted as one of the main shortcomings the absence of a single resource for obtaining a full amount of information about tourist infrastructure, events, objects of tourist interest in Ugra.

The analysis of the data also showed that there is a steady trend in the growth of the number of independent travelers, mainly in the national segment, and a decrease in the number of travelers in organized tourist groups. At the same time, the role of impressions is increasing and the importance of rational factors determining the destination of the trip is decreasing. This fact should be taken into account when choosing channels and format of promotion of information about tourist opportunities of Ugra. It also seems important when creating information content to emphasize the removal of biases about travel to Ugra, which are common among residents of the Russian Federation and foreign citizens. The existence of stereotypes may not be supported by objective facts, but it does indicate a lack of awareness among potential tourists. At the current stage of the development of marketing of destinations and in accordance with the Strategy for the Development of Tourism in the Russian Federation until 2035, the following instruments for the promotion of the tourist territory can be recommended:

- Creation and development of user interfaces and functions of a single tourist platform combined with the digitalization of promotion tools;

- Creation of communities on social media outlets and streaming video broadcasting services with information and cognitive content;

- Integration of the tourist product into user-friendly communication services - navigation and mapping services, voice assistants, ticket shopping applications, etc.;

- Promotion using marketing strategies built on technologies to study and predict consumer preferences, etc.

Based on the documents described above and data from the interviews, it is necessary to develop an integrated approach to the choice of targeting internal and external markets and to the identification of consumer segments to improve the tourism attractiveness of the region. Implementation of this direction is impossible without regular marketing research, which allows us to analyze and determine consumer preferences, barriers, and biases, as well as to form a value offer, identifying the most effective channels of communication with each segment of the target audience. The value proposition should be tailored to the specifics of the selected markets. For this purpose, the following activities should be implemented:

1) to explore the priority markets for the promotion of tourism potential in the territory of the Russian Federation and beyond;

2) integrate the created information content with the "portfolio of brands" of Ugra (Concepts of development of territorial marketing and branding in Khanty-Mansi Autonomous District - Ugra until 2025 (approved by the Resolution of the Government of Khanty-Mansi Autonomous District - Ugra of June 1, 2012, № 195-p); 3 ) to create an unified tourism platform of Ugra and content promotion of tourism potential in social networks with the involvement of tourist information centers in municipalities;

4) to optimize the operation of HMAO-Ugra TIC system;

5) to organize a presentation of the Tourism Gallery of the Autonomous District within the framework of major industry exhibitions and international business events, to hold business breakfasts/workshops for representatives of the tourism industry in the regions of priority marketing;

6) promotion of tourism opportunities of Ugra within the framework of major event events in the autonomous district, as well as neighboring regions (cities) of priority marketing.

\section{CONCLUSION}

Therefore, a competent marketing policy can increase the flow of tourists and ensure the success of destinations, the main results of the innovation will be:

1) access to key markets and increase their awareness of Ugra tourism products;

2) strengthening the sustainable image of Ugra as a tourist territory;

3) increasing the level of awareness of the population of the Autonomous district about objects of tourist interest, created infrastructure, event events;

4) increase in target audience coverage (number of readers/viewers/visitors/users of Ugra marketing activities, as well as audience coverage through external media);

5) increase the level of awareness of the target audience about the Ugra tourist tourism (percentage of informed 
[2] The concept for the development of territorial marketing and branding in the Khanty-Mansi

Autonomous Okrug - Ugra until 2025, approved by the Order of the government of the Khanty-Mansi

Autonomous Okrug - Ugra dated October 19, 2018 No. 539-RP

[3] E.A. Jangurazov, Marketing of tourist areas: proc. student's guide, Moscow, Publishing center "Academy", 2006, 224 p.

[4] A. Dinis, Territorial Marketing: A Useful Tool for Competitiveness of Rural and Peripheral Areas. A Paper presented at the 44th European Congress of ERSA in Porto, Portugal, 25-29 August, 2004

[5] E.A. Kachalin, Marketing territory, Ulyanovsk, UISTU, 2014, 127 p.

[6] F. Kotler, Marketing of places. Attracting investments, enterprises, residents and tourists to cities, communes, regions and countries of Europe / F. Kotler, K. Asplund, I. Rein, D. Haider, SPb, Publisher "Stockholm school of Economics", 2005, 382 p.
[1] UNWTO Tourism barometer, in: UNWTO elibraryб 2010, Vol. 08/Issue 01, URL: http://www.unwto.org/ facts/eng/pdf/barometer/UNWTO_

Barom10_1_en_excerpt.pdf (date of access:

07.03.2020) 